\section{Piotr Gorliński-Kucik}

Uniwersytet Śląski http://orcid.org/0000-0003-3733-4023

\title{
Metafory Parnickiego. Teologia i granice nowoczesności
}

\section{Abstract \\ Parnicki and his Metaphors. Theology and the Borders of Modernity}

This article offers an interpretation of the novel "Zabij Kleopatre" (1968) by Teodor Parnicki. Thanks to post-secular reflection, it is possible to situate the writer as a watchful observer of the so-called "exhaustion of modernity." This interpretation is based on a detailed analysis - through the disintegration of the generic determinants of the novel, the meta-literary level is gradually constructed to support a post-secular reading. "Zabij Kleopatrę" can be regarded as a breakthrough novel among Parnicki's writings.

Słowa kluczowe: literatura, teologia, postsekularyzm, nowoczesność, Teodor Parnicki

Keywords: literature, theology, postsecularism, modernity, Teodor Parnicki

\section{„Zabij Kleopatre” i przełomy}

Zamierzam podjąć próbę ukazania Teodora Parnickiego jako prozaika, którego powieści można poddać lekturze postsekularnej. Nie chciałbym uznawać go za pisarza postsekularnego ani nawet żadnej z jego powieści określić tym mianem, uważam jednak, że niektóre wątki z jego powieści można interpretować za pomocą tego dyskursu. 
Argumentów przesądzających o postsekularyzmie Parnickiego nie znajdziemy, ani przyglądając się jego biografii, ani analizując poetykę gatunku, który uprawiał. Jeśli chodzi o jego biografię, wciąż czekającą na napisanie, to jest ona pełna niejasności i niezwykle frapująca, ale nie wyjątkowa. Wielu jego rówieśników miało losy pokiereszowane przez historię XX wieku, szczególnie brutalnie obchodzącą się z tymi, którzy nie wpisywali się w wyraźnie zdefiniowane porządki: narodowe, wyznaniowe czy polityczne. Parnicki był pół-Żydem polsko-niemieckiego pochodzenia, urodzonym w Niemczech, wychowanym w Rosji, wykształconym w polskiej kolonii w wielokulturowym Harbinie, który kilka dekad spędził na emigracji w Meksyku¹. Jego dom rodzinny był prawdopodobnie laicki, nie wiemy, czy Parnicki był obrzezany, nie wiemy też, gdzie i kiedy został ochrzczony. Wiadomo, że był katolikiem, ale tylko przez kilka dekad - dopóki sam z katolicyzmu nie zrezygnował' ${ }^{2}$. Zatem w lekturze postsekularnej decydujący nie będzie żaden argument mający źródto w biografii pisarza.

A poetyka? Jako autor powieści historycznych Parnicki dbał o bardzo solidne przygotowanie swoich utworów, zarówno w zakresie historii ogólnej, jak i historii szczegółowych (głównie - historii idei, Kościoła, literatury). $\mathrm{Na}$ celu miał pokrzepianie umysłów, nie serc ${ }^{3}$, a więc bardziej niż barwne opisy militarnych starć interesowały go intelektualne debaty bohaterów. Co jednak wyróżnia Parnickiego spośród innych powieściopisarzy historycznych, to udana literacko realizacja założenia, że ideologiczne spory i rozterki (np. subtelne różnice w kształtujących się doktrynach wczesnego chrześcijaństwa) miały realny i przemożny wpływ na jednostki, na ich emocje, zachowania i dokonywane przez nie wybory.

Możemy wyróżnić trzy zasadnicze okresy twórczości autora Słowa i ciata. W „okresie młodzieńczym” powstały takie powieści, jak Aecjusz, ostatni Rzymianin czy Srebrne orly - to czas, w którym Parnicki zostaje pisarzem historycznym. Drugi okres, „dojrzały”, rozpoczyna Koniec „Zgody Narodów” oraz Stowo i ciało. Możemy w nim umieścić trzy tomy Twarzy księżyca, pięć

${ }^{1}$ Urodził się w roku 1908 w Charlottenburgu pod Berlinem, jego matką była pochodząca z Kijowa Żydówka - Augustyna z Piekarskich. Ze względu na pracę ojca - Bronisława - rodzina przeniosła się do Rosji, i to rosyjski był pierwszym językiem pisarza. Parnicki uczył się w polskim Gimnazjum im. H. Sienkiewicza w Harbinie, potem studiował we Lwowie. W Meksyku przebywał w latach 1944-1967.

2 Jego zdaniem ze wspólnoty wiernych wykluczył go rozwód z Elżbietą i drugi ożenek - z Eleonorą. Nie był też w stanie zaakceptować ogłoszonego w 1950 roku przez papieża Piusa XII dogmatu o cielesnym wniebowzięciu Matki Boskiej.

${ }^{3}$ „To nie jest tak, ja nie jestem przeciwnikiem pokrzepiania serc. Ale uważam, że należy raczej pokrzepiać mózgi, i dlatego kładłem w swoich powieściach akcent na te epoki w dziejach ludzkości w ogóle, a szczególnie w dziejach Polski, gdzie właśnie jest się czym chwalić w kategoriach intelektualnych" (T. Parnicki, Historia w literature przekuwana, Warszawa 1980, s. 415). 
tomów Nowej baśni i kilka innych ważnych powieści. Pisarz długo wykuwał nową poetykę powieści historycznej, poświęcając się wpierw lekturom i próbom w meksykańskiej samotni ${ }^{4}$, ale gdy już przełamał wydawniczy impas (spowodowany jego sytuacją emigracyjną i polityką wydawniczą PRL), opublikował trzynaście powieści w ciągu dekady. Łączą je motywy fabularne, poetyka powieści epistolarnej, dialogi urojone oraz charakterystyczny język, który zbliża się do języka prozy poetyckiej. Małgorzata Czermińska ${ }^{5}$ zauważyła, że już wtedy obecna jest w pisarstwie Parnickiego także ,„powieściowa metodologia powieści”, operująca rozmaitymi środkami, w tym „wypowiedziami w dziele o dziele"7. Trzeci okres, tak zwany późny Parnicki, to powieści z mocno wyeksponowaną metaliterackością, realizującą się między innymi w trylogii Tożsamość, Przeobrażenie i Sekret trzeciego Izajasza.

Uznaję „Zabij Kleopatrę” za tekst wyznaczający moment przejścia pomiędzy drugim (,dojrzałym”) a trzecim (,,późnym”) okresem twórczości ${ }^{8}$ autora Słowa i ciała i temu właśnie przekształceniu chcę poświęcić uwagę. $\mathrm{Na}$ płaszczyźnie fabularnej powieść ta stanowi ,zwornik dwu cykli”, łączy bowiem względnie rozłączne dotąd gałęzie twórczości prozaika - cykl o czasach antycznych oraz średniowieczno-nowożytnych. Jest to o tyle ważne, że odtąd możemy mówić o swoistym uniwersum Parnickiego, czyli wspólnym świecie wszystkich jego bohaterów ${ }^{10}$ oraz kilkudziesięciu powieści ${ }^{11}$. Także dlatego możemy potraktować całą jego twórczość jako jeden (względnie) spójny tekst rozpisany na blisko trzydzieści tomów prozy.

Powieść „Zabij Kleopatrę” została opublikowana w roku 1968, a więc w okresie kluczowych zmian dokonujących się zarówno w sferze polityczno-społecznej (w Polsce i Europie Zachodniej), jak i dziejach zachodniej huma-

${ }^{4} \mathrm{O}$ „meksykańskiej samotni” i długo trwającym przeformułowaniu poetyki piszę [w:] P. Gorliński-Kucik, Meksykańskie lata Teodora Parnickiego [w:] Literatura polska obu Ameryk. Studia i szkice. Seria pierwsza, red. B. Nowacka, B. Szałasta-Rogowska, Katowice-Toronto 2014, s. 589-605.

${ }_{5}^{5}$ M. Czermińska, Autotematyczność i dystans czasowy w powieściach Parnickiego [w:] O prozie polskiej XX wieku, red. A. Hutnikiewicz, H. Zaworska, Wrocław 1971, s. 314.

${ }^{6}$ M. Głowiński, Powieść jako metodologia powieści [w:] idem, Porządek, chaos, znaczenie. Szkice o powieści wspótczesnej, Warszawa 1968, s. 90-136.

${ }^{7}$ D. Danek, O polemice literackiej w powieści, Warszawa 1972.

${ }^{8}$ Trzeba tu zaznaczyć, że w podobny sposób wątki metaliterackie zostały wyeksponowane w V tomie Nowej baśni, wydanej w tym samym 1968 roku.

9 Zob. M. Czermińska, Teodor Parnicki, Warszawa 1974, s. 141-153.

${ }_{10}$ Wspólny dla utworów Parnickiego jest także opowiadający, Narrator Główny, którego jako „kreację liryczną” opisał po raz pierwszy Jacek Łukasiewicz. Zob. idem, ,, Gliniane dzbany" [w:] idem, Republika mieszańców, Wrocław 1974, s. 235-250.

${ }_{11}$ Terminu ,uniwersum” w odniesieniu do świata przedstawionego powieści Parnickiego użyła Małgorzata Czermińska. Zob. eadem, Autotematyczność i dystans czasowy..., s. 329. 
nistyki. Czy była jednym z rozproszonych głosów zapowiadających zmianę i jednocześnie będących jej przejawem? Sądzę, że tak, i w dalszej części artykułu postaram się to udowodnić.

Publikacja tej powieści zbiega się $\mathrm{z}$ jeszcze jednym ważnym przełomem - tym razem w pisarskiej biografii samego Parnickiego. Kiedy pisarz wraca z meksykańskiej emigracji (co stanowi dla ówczesnych władz i kręgów PAX-owskich znaczący sukces propagandowy), ma na swoim koncie kilkanaście trudnych i wymagających powieści historycznych, wiele nagród i cały wynikający z tego splendor. I gdy wydaje się, że wreszcie on i jego czytelnicy zbliżą się do siebie, dzieje się coś zupełnie odwrotnego. Czytelnicy - już jako tako oswojeni z nietypową prozą Parnickiego - prawdopodobnie oczekiwali kolejnych podobnych powieści, tymczasem on przygotowywał zwrot w stronę jeszcze bardziej ambitnego i trudniejszego w odbiorze pisarstwa. Zmiana poetyki w połączeniu $\mathrm{z}$ brakiem wsparcia promocyjnego spowodowała znaczący spadek zainteresowania krytyki ${ }^{12}$ i czytelniczej popularności Parnickiego, a w rezultacie jego kryzys twórczy. Choć już we wcześniejszych powieściach Parnickiego pojawiały się pewne „symptomy” metaliterackości, dopiero w „Zabij Kleopatrę” pisarz wkracza na teren, na którym metaliterackość jest nie tyle wyeksponowana, ile konstruowana na oczach czytelnika (i postaci!), aż w końcu staje się dominantą utworu. W kolejnych powieściach poziom meta- będzie już od samego początku wyraźnie zaznaczony, stanie się główną osią i ważnym wyróżnikiem „,późnej” twórczości.

Służy temu również dekonstrukcja podstawowych wyznaczników gatunku. Poetyka powieści zostaje rozłożona na czynniki pierwsze, a następnie poddana modyfikacjom. W rezultacie powstaje „traktat o antypowieści” ${ }^{13}$ lub raczej, paradoksalnie, ,antytraktat o powieści”, będący próbą nowej formy. Ten skomplikowany proces zaczyna się od zanegowania ustalonych zasad komunikacji w obrębie utworu literackiego.

${ }^{12}$ W roku 1973 Przeobrażenie i Staliśmy jak dwa sny zbierają w sumie pięć recenzji, rok później pojawiają się jeszcze trzy.

${ }^{13}$ Sam Parnicki protestował, gdy jego utwory nazywano antypowieściami, chodziło tu jednak o porównania do „nouveau roman”: „Antypowieść? Sarraute. Butora czytałem niedawno i nie odnajduję w sobie żadnego pokrewieństwa duchowego czy programowego. Irytuje mnie, gdy doczepia się moim książkom przyczepkę »antypowieści«” (K. Mętrak, „Powieść to jakby rozwiazywanie tamigłówki... ”. Rozmowa z Teodorem Parnickim, „Kultura" 1968 , nr 32, s. 3). 


\section{Rozpad (powieściowości) i konstruowanie (metafory)}

W „Części pierwszej” powieści „Zabij Kleopatrę” Parnicki korzysta jeszcze ze względnie tradycyjnej formuły literackiej, którą wypracowywał w latach sześćdziesiątych. Mamy tu do czynienia z epiką historyczną w konwencji powieści epistolarnej o budowie szkatułkowej. Pierwszy rozdział zawiera trzy listy Hermanaryka do Apolonii i dwie odpowiedzi, datowane na rok 472. Ich tematem jest między innymi bogoznawstwo lub chrystoznawstwo, a także wydarzenia dotyczące biografii obojga piszących i wydarzeń, w jakie byli uwikłani. W drugim rozdziale czytają oni listy Eulogiosa do Dionizji z roku 467, w których przytaczane są fragmenty protokołów z procesu sądowego w sprawie przyznania Dionizji spadku po Aigidiosie (proces ten miał się odbyć właśnie w roku 467).

Trzeci rozdział przynosi protokoły innego procesu, także z roku 467, ale rozpoczętego zaraz po procesie w sprawie spadku - to sąd nad Isokasjosem. Mamy tu zatem do czynienia z dwiema głównymi płaszczyznami czasowymi (lata 472 i 467) oraz dwiema retrospekcjami odnoszącymi się do procesów sądowych, a także licznymi odwołaniami do wydarzeń jeszcze wcześniejszych, które pojawiają się w zeznaniach świadków.

W rozdziale czwartym wracamy do roku 472 i korespondencji Apolonii z Hermanarykiem. Tym razem czytają oni i komentują zapis ostatniej, piątej rozprawy przeciw Isokasjosowi, dotąd utajonej. „Część pierwsza” powieści „Zabij Kleopatrę” jest więc powieścią szkatułkową, w której następuje inwersja czasowa. Ukryty narrator używa trzech form podawczych: listów, urojonych dialogów oraz zapisów sądowych. Ramowa akcja utworu rozgrywa się w twierdzy Cherrys w roku 472, a fabuła sięga o wiele głębiej, bo za sprawą odwołań w tekście powieści aż do roku 30 p.n.e. Czytelnik cierpliwy, czytający z ołówkiem w ręku, jest w stanie w dużym stopniu tę fabułę zrekonstruować.

Jednak właśnie w czwartym rozdziale po raz pierwszy naruszona zostanie kluczowa dla epiki narracyjnej (w tym powieści historycznej) iluzja niezależności wydarzeń fabularnych względem podmiotu narracji. Dzieje się tak w momencie, gdy Eulogios przecząco odpowiada na pytanie eparchy, czy ten może wydać wyrok skazujący Isokasjosa na śmierć, i uzasadnia swoją odpowiedź następująco: „Twierdzą bowiem dziejopisarze z czasów przyszłych, że eparcha Puseus wydał w sprawie Isokasjosa wyrok [...] uniewinniający"14 (ZK, s. 180). Nie bez powodu zapis ostatniej części procesu został ukryty. Odizolowani i odcięci od świata bohaterowie nagle orientują się, że nie tylko

14 Na przełomowy charakter tego zdania zwracają uwagę Małgorzata Czermińska (zob. M. Czermińska, Teodor Parnicki, Warszawa 1974, s. 141-142) oraz Krzysztof Uniłowski w artykule będącym szczegółowym omówieniem „Zabij Kleopatrę” (zob. K. Uniłowski, Historia, dekonstrukcja, metaproza. O dwóch powieściach Teodora Parnickiego 
znają przyszłość, ale też są bohaterami powieści pisanej przez nieznanego im autora. Do takiego samego wniosku dochodzi czytający ten zapis Hermanaryk i od razu wykorzystuje ten fakt do realizacji swoich planów: skoro jest postacią literacką, to mógłby wbrew historii ożenić się z kochaną przez siebie Apolonią, a nie z jej córką.

Wracam teraz do ostatniego zapisu procesu, w którym następuje pierwszy akt ujawnienia konwencji powieściowej, co z kolei doprowadzi (już w kolejnych częściach utworu) do reakcji łańcuchowej i destabilizacji pozostałych wyznaczników gatunku. Postaci rozważają swoją sytuację i choć zdają sobie sprawę, że ich poznanie jest ograniczone (,Zaiste obijanie się jest to ćmy o lampę!” - ZK, s. 185), to dochodzą do wniosku, iż autor jest ,poprawiaczem", który dowolnie modyfikuje notarialny zapis rozmów. Oni sami rzeczywiście istnieli - świadczą o tym wzmianki w historycznych świadectwach z epoki (ZK, s. 192) - ale przytoczone protokoły procesu są już najpewniej dziełem pisarza. Nazywają go nawet „wskrzesicielem” (ZK, s. 200), który ich literacko ożywił. Przypisują mu cechy boskie, a jego relację z tekstem rozpatrują w ramach religijnych relacji twórca - stworzenie. Sam autor stopniowo ujawnia się w tekście, najpierw przez uwolnienie Notarii (,wyjście jej już z więzów nawiasowości” - ZK, s. 198) i dopiski dotyczące jej pragnień („wolałaby przecież napisać...” - ZK, s. 182), a następnie przez kontrolowanie bohaterów - na przykład w rozmowie o przyszłości Aspara. Tu nawet eparcha (z poruczenia autora) gromi towarzyszy odizolowania: „Nie wolno o tym mówić!’ (ZK, s. 194). W końcu fikcyjny autor przekazuje swe polecenia przez Notarię (ZK, s. 203).

W „Części pierwszej” powieści mamy zatem do czynienia z czterema istotnymi składnikami gestu metaliterackiego. Są nimi: nadanie postaciom świadomości swojej tekstualności, dyskretne ujawnienie się piszącego, odizolowanie postaci oraz zaburzenie między piętrami komunikacji w tekście literackim.

„Intermezzo" tylko na moment łagodzi odczucie rozpadu powieściowości. „Część druga” wprowadza bowiem dialogi postaci z narratorem, a później także z autorem fikcyjnym. W pierwszym podrozdziale rozmawiają Eulogios i Maksymian, w drugim odzywa się Jan XXII (ZK, s. 224), papież żyjący na przełomie XIII i XIV wieku. Jeśli autorem „Części pierwszej” faktycznie jest Tarantula (czyli Stanisław Polak), to późniejszy autor „Części drugiej” mógł wykorzystać jego postać jako bohatera ${ }^{15}$. Jeśli jednak przyjmiemy, że ujaw-

[w:] idem, Prawo krytyki. O nowoczesnym i ponowoczesnym pojmowaniu literatury, Katowice 2013, s. 123-148). Cytując w tekście fragmenty z tomu „Zabij Kleopatrę”, stosuję skrót ZK i podaję numer strony.

${ }_{15}$ Mógłbym, co prawda, sprowadzić narratora do roli bohatera, lecz to nie tylko unieważniłoby wszystkie poniższe rozważania, ale też wagę gestu samego Parnickiego. „Powinieneś był postawić sprawę tę samą inaczej: jak ja znęcałem się nad postaciami części pierwszej, tak samo z kolei pastwić się zacznie nade mną autor drugiej” (ZK, s. 242-243) - 
nieni w tekście narrator i autor rzeczywiście pochodzą z ,wyższego” piętra instancji nadawczych tekstu, będziemy mieli do czynienia nie tylko ze szkatułkowością á rebours (co udowodnią jeszcze „Część trzecia” oraz „Epilog”), ale także z zaburzeniem klasycznego schematu relacji osobowych w komunikacji literackiej oraz zwielokrotnieniem jego struktury. Wyglądałoby to zatem tak ${ }^{16}$.

\begin{tabular}{|c|c|c|c|}
\hline & Instancje nadawcze & Odbiorca & Szkatułka á rebours \\
\hline \multirow[t]{3}{*}{ Wewnątrztekstowe } & Postać & Postać & \multirow[t]{2}{*}{ Trzy części } \\
\hline & $\begin{array}{l}\text { Narrator } \\
\text { (z dyspozycji autora } \\
\text { danej części) }\end{array}$ & Adresat narracji & \\
\hline & $\begin{array}{l}\text { Podmiot utworu } \\
\text { (Autor trzech } \\
\text { części, Epilogu } \\
\text { i Intermezza) }\end{array}$ & $\begin{array}{l}\text { Adresat utworu } \\
\text { (otoczenie P., autora } \\
\text { powieściowego) }\end{array}$ & $\begin{array}{l}\text { Epilog - ostatnie } \\
\text { piętro }\end{array}$ \\
\hline \multirow[t]{2}{*}{ Zewnątrztekstowe } & $\begin{array}{l}\text { Podmiot czynności } \\
\text { twórczych } \\
\text { (autor ,Zabij } \\
\text { Kleopatrę”, wyd. } \\
\text { PAX, Warszawa } \\
\text { 1968) } \\
\end{array}$ & Czytelnik idealny & \multirow[t]{2}{*}{$\begin{array}{l}\text { Sytuacja } \\
\text { zewnątrztekstowa }\end{array}$} \\
\hline & $\begin{array}{l}\text { Autor realny } \\
\text { (Teodor Parnicki) }\end{array}$ & Czytelnik konkretny & \\
\hline
\end{tabular}

Opieram się na założeniu, że „Epilog” jest ostatnim piętrem utworu i że Antoni Parznicki jest powieściowym autorem trzech części romansu „Zabij Kleopatrę". Nie lekceważę wszakże uwagi Jezuity:

mówi Tarantula; ma więc, jako postać „Części drugiej”, świadomość, że jest autorem „Części pierwszej”, nadaną mu najpewniej przez powieściowego autora wszystkich trzech części - zob. olejny cytat już z „Części trzeciej”: „Uspołeczniłeś się (zwrot to naszym czasom nieznany, ale ON go pozna!) najdoskonalej” (ZK, s. 327).

${ }^{16}$ Posługuję się tabelą podsumowującą rozważania zawarte w: A. Okopień-Sławińska, Relacje osobowe w literackiej komunikacji [w:] Problemy teorii literatury, S. 2: Prace z lat 1965-1974, red. H. Markiewicz, Wrocław 1987, s. 41. Poddaję ją pewnym modyfikacjom, między innymi zamiast „bohatera” wpisuję „postać”, bowiem: „W XVII wieku powieść była jeszcze namiastką epopei, fascynowała się tylko faktem, nie znała postaci (personnage), ale bohaterów (héros). Postać jako jednostka ukształtowała się w powieści na początku XIX wieku wraz z porządkiem burżuazyjnym”. Zob. M. Głowiński, ,Nouveau roman”problemy teoretyczne [w:] idem, Porządek, chaos, znaczenie..., s. 72). Jednak w tekście określeń „postać” i „,bohater” używam zamiennie. 
W pokoju sąsiednim może znajdować się NOTARIA i sporządzać zapis rozmowy tej naszej. Jakiś przetwórca czy dotwórca osobowości naszych w wieku przyszłym lub później jeszcze zapis ten wykorzystać mógłby w taki właśnie sposób, by okazało się, że to, co teraz dzieje się między nami tutaj, jest ciągiem dalszym rozmowy [...] w części czwartej (ZK, s. 426-427).

„Odcinam” jednak trzy części od „Epilogu”, aby móc dokonać pewnych ustaleń. Parnicki multiplikuje instancje nadawcze na poziomie ,podmiotu utworu", mnożąc fikcyjnych nadawców, którym przysługuje niejasny empiryczno-tekstowy status. Notaria w protokole piątej rozprawy nad Isokasjosem mówi:

NOTARIA: [...] Możliwościami przecież rozporządza ograniczonymi, iżby wam pomógł [twórca - przyp. P.G.K.]. Ma nad sobą...

ISOKASJOS: Boskość.

NOTARIA: Nie tylko. Bo kogoś jeszcze między sobą a boskością.

Powiedziałam: kogoś? Równie dobrze powiedzieć mogłam: ma coś między sobą a boskością. Nieraz wielka to moc być kimś. [...] Lecz powinnam też rzec: straszliwa odpowiedzialność również. Straszliwa i dla podmiotu mocy, i dla przedmiotu. A właśnie przedmiotem mocy tej jest nasz w przyszłości odtwórca. Ależ żeby tylko przedmiotem! Miłośnikiem też mocy tej jest (ZK, s. 205).

Czy fragment ten pozwala na usytuowanie autora (posiadającego także cechy boskości) na drabinie bytów, na której ostatnie, odległe miejsce zajmuje Bóg?

Przyjąłem powyżej dwa założenia: że ujawniony w tekście narrator nie jest jedynie postacią oraz że „Epilog” jest ostatnim wewnątrztekstowym piętrem odwróconej szkatułki. Dzieje się jednak w końcu i tak (po raz pierwszy wyraźnie w podrozdziale piątym rozdziału drugiego „Części drugiej” - ZK, s. 284), że sam autor objawia się i bierze udział w rozmowie bohaterów i narratora. Tego autora nie możemy jednak utożsamiać z podmiotem utworu - jest nim bowiem P., fikcyjny autor całości utworu (tym samym autor „Części drugiej” staje się ,autorem rzekomym”). Innymi słowy, każdy z trzech powieściowych autorów dysponuje swoim narratorem ${ }^{17}$, a niejako ponad nimi występuje nadrzędny, ale nadal fikcyjny, autor całej powieści - P. (pomijam oczywiście autora realnego - Teodora Parnickiego). Tabela po rozdzieleniu narratora i autora każdej części przybrałaby więc następującą formę:

17 „Jest NARRATOR gawędy tej jedynie bezwolnym wykonawcą woli autora części drugiej dzieła pod tytułem "Zabij Kleopatrę«, więc co mu nakazane jest, to i opowiada" (ZK, s. 245). 


\begin{tabular}{|l|l|l|}
\hline Postać & Postać & Trzy części \\
\cline { 1 - 2 } Narrator & Adresat narracji & \\
\cline { 1 - 2 } Autor danej części & Adresat danej części & \multirow{2}{*}{ Epilog - ostatnie piętro } \\
\cline { 1 - 1 } $\begin{array}{l}\text { Podmiot utworu } \\
\text { (Autor trzech części, } \\
\text { Epilogu i Intermezza) }\end{array}$ & Adresat utworu & \\
\hline
\end{tabular}

Ostatnia tabela przedstawia domniemane (wedle każdej z części) instancje nadawcze i adresatów powieści.

\begin{tabular}{|l|l|l|l|l|}
\hline Według: $\rightarrow$ & $\begin{array}{l}\text { Części } \\
\text { pierwszej } \\
\text { (autor / adresat) }\end{array}$ & $\begin{array}{l}\text { Części drugiej } \\
\text { (autor / adresat) }\end{array}$ & $\begin{array}{l}\text { Części trzeciej } \\
\text { (autor / adresat) }\end{array}$ & $\begin{array}{l}\text { Epilogu } \\
\text { (autor / adresat) }\end{array}$ \\
\cline { 1 - 4 } Część pierwsza & $? / ?$ & $\begin{array}{l}\text { Tarantula / } \\
\text { Jan XXII }\end{array}$ & Diaz / ? & P. / \\
otoczenie P.
\end{tabular}

Skomplikowana struktura utworu generuje zarówno instancje nadawcze, jak i odbiorców. Jednak fikcyjni czytelnicy to stosunkowo wąskie grono osób wtajemniczonych w treść tajnych zbiorów (I u możnych dziwny) czy nadzbiorów (Nowa baśń).

Podstawową formą podawczą narracji w „Zabij Kleopatrę” jest dialog urojony. Jeżeli przyjmiemy, że tekst powieści jest raczej prozą poetycką, monologiem rozpisanym na głosy, niż polifonią ${ }^{18}$, to staje się on opowieścią Narratora Głównego, który rozmawia sam ze sobą. Moglibyśmy więc uznać, że całość powieści dzieje się po prostu w wyobraźni autora rzeczywistego, czyli - innymi słowy - „w głowie Parnickiego”. Dojść do takiego wniosku można jednak jeszcze inną drogą.

Postaci biorące udział w procesie Isokasjosa zostają umieszczone w (Dantejskich) Zaświatach, gdzie toczy się dalsza część akcji. Sytuacja komplikuje się, gdy rozmawiać zaczną ze sobą bohaterowie pochodzący z różnych historycznych płaszczyzn czasowych. Gdzie zatem następuje ich spotkanie? Wydaje się, że w „lokacji” oderwanej od czasu i przestrzeni, która jest swoistą ekskluzją ${ }^{19}$, obszarem wyjętym ze świata przedstawionego powieści histo-

${ }_{18}$ Nie mam tu na myśli stricte Bachtinowskiego rozumienia polifonii, ale raczej takie, jakie (w odniesieniu do Parnickiego) prezentuje Andrzej Juszczyk. Zob. A. Juszczyk, Retoryka a poznanie. Powieściopisarstwo Teodora Parnickiego, Kraków 2004.

19 Inkluzję rozumiem jako podzbiór (danego zbioru, nazywanego nadzbiorem) składający się z pewnej liczby elementów. Jeśli nie zawiera żadnego elementu - jest podzbiorem pustym, jeśli jeden - podzbiorem jednoelementowym, jeśli zaś wszystkie elementy - pod- 
rycznej. Postaci są do niej skopiowane, jeśli uznać, że istnieją nadal w swoim świecie (przykład: ,[...] sądzę Isokasjosa, bo wszak będzie posłował do króla VANDALORVM Gejzeryka za siedem lat od dzisiaj [...]" - ZK, s. 187); lub wskrzeszone $^{20}$, jeśli uznamy, że późniejszy od nich autor powołuje je do ponownego życia w literaturze na podstawie przeczytanych przez siebie tekstów źródłowych i obdarza je świadomością wybranego momentu historycznego ${ }^{21}$.

O ile wyabstrahowana przestrzeń może być ekskluzją świata przedstawionego, o tyle musi być inkluzją fikcji: istnieje bowiem jako świat możliwy wewnątrz (a nie zewnątrz) świata aktualnego, jakim jest świat powieściowy. Nie wyklucza go, bowiem funkcjonuje jako koniunkcja $(i)$, a nie jako dysjunkcja czy alternatywa (albo/lub). Ekskluzja/inkluzja to swoista ,pamięć operacyjna", w której dokonują się zabiegi na postaciach skopiowanych do niej przez autora - jej istnienie nie wyklucza więc świata aktualnego. A światem aktualnym jest tu świat powieści historycznej, bowiem ta ,zawsze konstruuje fikcję literacką, czyli [...] przedstawia świat jako w ramach paktu zawartego między nadawcą i odbiorcą - aktualny"22. Mamy więc do czynienia z podwójnym paktem nadawcy i odbiorcy ${ }^{23}$.

zbiorem niewłaściwym. Jeśli ekskluzja oznacza wykluczenie, odrzucenie czy izolację od reszty, to tutaj ekskluzję rozumiem jako podzbiór znajdujący się niejako poza nadzbiorem i będący poza wpływem panujących w nim zasad.

${ }^{20} \mathrm{O}$ autorze pisze Czermińska: „Dla postaci powieściowych jest jednak stwórcą, wszechmocnym Bogiem. Pojmowanie artysty, pisarza jako kreatora, demiurga, wreszcie Boga pojawia się w wielu powieściach autora Nowej baśni, a także w jego wypowiedziach dyskursywnych [...]. Ich [postaci - przyp. P.G.K.] głównym argumentem w walce o istnienie niezawisłe od pisarskiej wyobraźni jest to, że władza pisarza jest ograniczona w stosunku do tych, którzy są postaciami znanymi ze źródeł historycznych. Wobec nich nie jest stwórcą, jedynie wskrzesicielem. Wszechmocnym kreatorem, dawcą życia jest wtedy, kiedy powieść [jest - przyp. P.G.K.] historyczno-fantastyczną". M. Czermińska, Teodor Parnicki..., s. 167-168. O Pisarzu-Demiurgu zob. też: M. Czermińska, Czas w powieściach Parnickiego, Warszawa 1972, s. 101-105.

${ }^{21}$ W swoich rozważaniach Jacek Łukasiewicz wychodzi od zatarcia granicy między autorem a bohaterem, aby dojść do problemu czasu. Wyróżnia cztery możliwe sposoby spotkania: czas autora (teraźniejszość), czas bohaterów (przeszłość), komunikacja poprzez czas oraz spotkanie w „czasie neutralnym”. Wydaje się, że w przypadku „Zabij Kleopatrę” najwłaściwsza jest właśnie czwarta forma, „czasu neutralnego”, a więc spotkania w ekskluzji/inkluzji. Zob. J. Łukasiewicz, „Pomnożyciel lat jego”... Teoria literatury, czyli teologia [w:] Świat Parnickiego. Materiały z konferencji, red. J. Łukasiewicz, Wrocław 1999, s. $188-189$.

22 A. Łebkowska, Fikcja jako możliwość. Z przemian prozy XX wieku, wyd. II uzup., Kraków 1998, s. 183.

${ }^{23}$ Pierwszy to pakt ustanawiający fikcję literacką (świat aktualny), a drugi - ustanawiający naszą ekskluzję/inkluzję, a więc fikcję w fikcji, czyli swoistą formę świata możliwego. Dalej pisze Łebkowska: „A zatem możliwy świat to [...] sposób, w jaki stan rzeczy mógłby być, czy inaczej: sposób, w jaki świat mógłby być”, a „każde zdanie w obrębie danego świata przybiera wartość prawdy lub fałszu" (ibidem, s. 43). Aktualność świata aktualnego 
Sądzę, że możemy ekskluzję/inkluzję uznać za specyficzną formę świata możliwego. Dalsze części poddają się podobnej analizie - akcja „Części drugiej” rozgrywa się w wieku XIV (pojawiają się w niej między innymi Tarantula i Jan XXII), akcja „Części trzeciej” w wieku XVII (to świat Z.). Znalazły się tam autocytaty z Tylko Beatrycze $e^{24} \mathrm{i}$ z powieści I u możnych dziwny ${ }^{25}$. Treść tych utworów jest włączona do „Zabij Kleopatrę” niejako „z zewnątrz” i staje się ona fikcją możliwą z terenu objętego już drugim z paktów zawartych z czytelnikiem (innymi słowy: Tarantula i Zagłoba trafiają od razu do ekskluzji/ inkluzji).

Te dwie „dołączone” płaszczyzny mają cechy światów możliwych także dlatego, że realizują wariantywne wersje tej samej historii: motyw zabicia królowej Egiptu Kleopatry VII użyty zostaje w wątku Apolonii; wątek Apolonii z V wieku - w historii Apolonii i Eugeniusza Taira w wieku XIV. Postać mima Dionizji jest z kolei użyta w historii Zagłoby (zespół opiekuńczy), a historię Zagłoby wykorzystuje P., by opowiedzieć o sobie samym. Dzięki tym wewnętrznym cytatom (nie bez przyczyny w tytule powieści pojawia się cudzysłów!) powieść staje się wewnętrznie parodystyczna (powtarza ze zmianą, rekontekstualizuje ${ }^{26}$ ). Oprócz tego mamy jeszcze do czynienia z późniejszymi pre-tekstami tekstu, czego dowodem mogą być słowa Tarantuli (rzekomego autora „Części pierwszej”, wypowiedziane, gdy występuje on już jako bohater „Części drugiej”): „Jest - przyznam się - Apolonia z części pierwszej jedynie przerzutem w czas miniony obecnie istniejącej” (ZK, s. 225).

Używałem dotąd języka teorii komunikacji literackiej, ale także takiego, który kierował nas w stronę rozumienia Parnickiego jako twórcy wirtualnych tekstowych światów, oderwanych od $\mathrm{czasu}^{27}$. O ile jednak postaci faktycznie zostają przeniesione do ekskluzji/inkluzji i stają się swoimi „kopiami operacyjnymi”, wyrwanymi z czasu historycznego, o tyle sama ekskluzja/inkluzja nie jest zupełnie od tego czasu oderwana. Ten tekstowy nowotwór funkcjonuje w czasie historycznym, odgrywa pewną rolę (na przykład polityczną), podlega

ujmowana jest pozaczasowo, ,zatem nie każdy możliwy świat jest światem aktualnym, [...] w zbiorze możliwych światów jeden jest aktualny, pozostałe - nieaktualne" (ibidem, s. 46).

${ }^{24}$ T. Parnicki, Tylko Beatrycze. Powieść historyczna, Wrocław 2001.

${ }^{25}$ Idem, I u możnych dziwny. Powieść z wieku XVII, Warszawa 1979.

${ }^{26}$ Mam tu na myśli takie rozumienie parodii, jakie prezentuje Linda Hutcheon. Zob. Eadem, Teoria parodii. Lekcja sztuki XX wieku, przeł. A. Wojtanowska, W. Wojtowicz, Wrocław 2007.

27 Zob. M. Szybist, Doktryna twórcza i sztuka T. Parnickiego, „Życie Literackie” 1971, nr 21, s. 3, 14. Zob. także propozycję odczytania Parnickiego w duchu Derridiańskiej dekonstrukcji: T. Komendant, Parnicki jak pismem sięgnać, „Polityka-Kultura” 1994, nr 5, s. VIII. 
wewnętrznym zmianom, jest przedmiotem gry: inaczej ten tekst pisze i traktuje Tarantula, inaczej - P. Znajdziemy tu także czytelne aluzje do Dantejskiego piekła $^{28}$. Parnicki nie odrywa się zatem od linearnego czasu historii.

Postaci „Zabij Kleopatrę” wykazują tendencję do swoistej multiplikacji. Powieść jest najpewniej dialogiem Narratora Głównego z samym sobą, lecz narrator „Części drugiej” doprowadza do rozmowy Eulogiosa i Maksymiana, mającej dowieść, że postaci te nie są tożsame (ZK, s. 218-222). Rozprawę ze sobą samym toczy także Mateusz Boniecki (ZK, s. 347-361).

Istnieje jednak wpływ prymarnego świata powieściowego na ekskluzję/ inkluzję. Zmieniają się warunki w niej panujące, gdy zmienia się doktryna teologiczna w wiekach średnich. Jeśli autorem „Części pierwszej” jest Tarantula, to pisał on dla Jana XXII właśnie po to, aby pokazać papieżowi konsekwencje tych doktrynalnych zmian. Przeniesienie bohaterów do ekskluzji/inkluzji prowadzi do zniesienia barier czasowych pomiędzy nimi.

Tak wyglądałaby sytuacja narracyjna w „Zabij Kleopatrę”. W tych rozdziałach powieści, których akcja rozgrywa się w ekskluzji/inkluzji, następuje zespolenie czasu fabuły, czasu akcji i czasu narracji. Ujawniony w tekście narrator bądź powieściowy autor (zakładam, że nie znajdują się oni na poziomie postaci) opowiada o tym, co się dzieje, biorąc udział w rozmowach bohaterów ${ }^{29}$. Narracja nie jest tym samym narracją unaoczniającą, jak w przypadku relacji z wydarzenia. Opowiadający mówi o tym, w czym bierze udział, a istotą tego wydarzenia jest to, że on sam bierze w nim udział (przenika ono na dodatek nie tylko kategorie czasu i miejsca, ale w specyficzny sposób wpływa także na narrację i fabułę, bowiem uczestniczy w niej sam opowiadający) ${ }^{30}$.

Jednak i ten splot - fabuły i narracji - jest szkatułkowy. Zakładając, że to Antoni Parznicki jest autorem trzech części, trzeba stwierdzić, że czas narracji w tym przypadku będzie już zupełnie inny. Aż do poziomu „Epilogu” szkatułkowość fabuły i narracji odnosi się osobno do każdej części.

Chciałbym jeszcze przypomnieć „fabułę pionową”, którą Stefan Szymutko zauważył w Stowie i ciele.

${ }^{28}$ „Jeżeli zaś kogoś zaciekawia szczególnie, dlaczego rozdział każdy ma pięć podrozdziałów, doradza się ciekawym zajrzenie do pieśni piątej Piekła Aligerusa. Właśnie do piątej. Jeszcze raz powtórzmy, a z naciskiem: właśnie do piątej” (ZK, s. 247). W drugim kręgu piekła przebywają dusze ludzi, ,[co] nad rozsądek wywyższyli chuci” - między innymi dusza Kleopatry. Zob. Dante Alighieri, Boska komedia, przeł. E. Porębowicz, Kraków 2003, s. 27-31.

${ }^{29}$ Pokazuje to, że narrator w pisarstwie Parnickiego coraz bardziej - z powieści na powieść - zbliża się do płaszczyzny świata przedstawionego, przestaje być transcendentny w stosunku do tekstu. Zob. K. Uniłowski, Metaliteratura w pisarstwie Parnickiego, „Pamiętnik Literacki” 1991, z. 2, s. 99-100.

${ }_{30}$ Wydaje się jednak, że to coś odmiennego od „zjawiska narracji momentalnej”. Zob. M. Głowiński, Narracja jako monolog wypowiedziany [w:] idem, Gry powieściowe. Szkice $z$ teorii i historii form narracyjnych, Warszawa 1973, s. 137. 
Fabuła rozwija się więc nie wzdłuż, ale w poprzek utworu - określić ją zatem można jako pionową [...] fabuła linearna (mimo licznych odgałęzień) jest jedna w utworze, fabuł pionowych - ze względu na uhistorycznienie bohaterów - musi być przynajmniej kilka [...]. W Słowie... w związku z tym można wydzielić pięć bloków fabularnych: Chozroes jako Chozroes, Chozroes w roli syna Zemsty, Markia wobec sprawy Syna Zemsty, Markia wobec sprawy Orygenesa, Markia jako Deipila $^{31}$.

Wydaje się, że fabułę pionową widać też w „Zabij Kleopatrę”, z tą tylko różnicą, iż postaci są tutaj bardziej utekstowione niż uhistorycznione. Kim innym jest Z. dla Jana XXII czy Eugeniusza, a kim innym dla postaci późniejszych - na przykład P. Jeszcze inaczej interpretują jego postać bohaterowie żyjący wcześniej (choć w ekskluzji/inkluzji - jednocześnie).

Pojawia się tu jeszcze cytat postaci, zabieg, którym Parnicki posłużył się wcześniej w powieści I u możnych dziwny ${ }^{32}$. Tutaj wykorzystuje ten sam chwyt w obrębie własnej twórczości, a nawet w obrębie jednego utworu.

Fabuła utworu rozpada się jeszcze w inny sposób. Niejednokrotnie postaci chcą w swych rozważaniach podjąć jakiś temat, ale ich rozmowa zbacza na tematy mniej istotne, związane z procedurą postępowania (w przypadku procesu) bądź ich zachowaniami. Tym samym fabułą utworu staje się narracja. Literatura - metaliteratura - mówi tu tylko o sobie, jest samozwrotna - niemal idealnie metaliteracka ${ }^{33}$.

Motywacją tych przeobrażeń jest także poznanie. W tym przypadku chodzi o poznanie czynności twórczej, a więc pisania. Przez pisanie o pisaniu mamy poznać pisanie.

31 S. Szymutko, Koniec porozumienia z odbiorca (O odmianie powieści historycznej, stworzonej przez T. Parnickiego) [w:] Studia o przemianach gatunkowych w powieści polskiej XX wieku, red. T. Bujnicki, Katowice 1987, s. 133-134.

${ }^{32}$ Zob. R. Koziołek, Co to jest Z.? Postać literacka w przestrzeni intertekstualnej: Parnickiego „, I u możnych dziwny”, „Pamiętnik Literacki” 1994, z. 1, s. 102-122.

${ }_{33}$ Może historycznoliterackim źródłem tego metaliterackiego gestu mógłby być motyw teatru w teatrze w Hamlecie Szekspira lub w Sześciu postaciach w poszukiwaniu autora Luigiego Pirandellao? Por. wypowiedź Parnickiego: „To chyba słuszne spostrzeżenie, tylko że co najmniej dwie trzecie moich książek powstało przed zapoznaniem się z twórczością Pirandella. Znałem tylko jeden jego utwór, mianowicie Henryka IV. Moja ostatnia książka "Zabij Kleopatrę« może zdradzać pewne pokrewieństwo z Pirandellem, ale też wydaje mi się, podświadome raczej" (Eamigłówki historii. Z Teodorem Parnickim rozmawia Krystyna Nastulanka, „Polityka” 1968, nr 9, s. 7). 


\section{Teologia pisania}

Pozwolę sobie na sformułowanie dwóch ogólnych wniosków płynących z zaproponowanej tu lektury. Pierwszy odnosi się do metaliterackości. Uwagę zwraca ekskluzja/inkluzja, określona już jako specyficzna forma wyobraźni autorskiej. Uwypuklenie roli wyobraźni autorskiej jest krokiem w stronę powieści historyczno-fantastycznej, gdzie akt pisania staje się generatorem rzeczywistości i poprzez podkreślenie fikcjonalności świata ani nie sprzeniewierza się faktom historycznym ${ }^{34}$, ani nie jest aktem epistemologicznego zwątpienia. Pisanie ma być drogą do poznania, ale „oscyluje między prawdą a zmyśleniem, między historią a poezją [...] w świadomości piszących łączy się wyobraźnia z rzeczywistością, gdyż wobec pisma są to sfery równoważne" ${ }^{35}$. Możemy więc trzymać się uporczywie faktów historycznych, ale i tak nie zagwarantuje nam to upragnionego poznania. Każde pisarstwo - jako że jest pisaniem stanowi twór wyobraźni, ekskluzję (ewentualnie inkluzję fikcji). Pisarz historyczny musi zawrzeć pakt z odbiorcą: powieść historyczna jest fikcją literacką (co nie przeszkadza jej być aktualnym światem wewnątrz powieści). Parnicki poprzez stworzenie ekskluzji/inkluzji i obdarzenie postaci świadomością ich fikcjonalności zdaje się zwracać uwagę właśnie na ten fakt. Można więc powiedzieć, że „Zabij Kleopatre”” jest swoistym symptomem przeobrażenia formy powieściowej. Przed tą cezurą forma powieści Parnickiego zbliżała się do klasycznej (choć i tak specyficznej) powieści historycznej - a po tej cezurze coraz bardziej uwydatnia metaliterackość oraz podkreśla zabiegi dokonywane na prawdzie historycznej i fikcji literackiej.

Drugi wniosek kieruje nas w stronę lektury postsekularnej, którą nazywam na razie teologią literatury. W obrębie pisarstwa literaturoznawczego możemy nakreślić triadę: tekst - krytyka literacka - teoria literatury, gdzie teoria reprezentuje naukę o literaturze jako jej gałąż $z^{36}$. Ma ona funkcję bardziej opisową niż normatywną. Krytyka literacka zaś ma w swojej naturze funkcję projektującą: próbuje wpływać zarówno na pisarza, jak i na czytelnika.

W pisarstwie Parnickiego triada ta wyglądałaby trochę inaczej. Tutaj utekstowiony świat podlega krytyce, która z czasem przeradza się w teologię. Bogiem tego tekstowego świata jest autor, pisarz. Krytyka to analiza i ocena dokonywana z określonego punktu widzenia. Teologia zaś próbuje badać Boga i jego stosunek do świata (w tym przypadku: pisarza i jego stosunek do dzieła/tekstu).

Zaraz po zamknięciu uczestników procesu nad Isokasjosem rozpoczyna się gorąca debata, której uczestnicy próbują dociec, czy pisarz jest twórcą, czy

${ }^{34}$ K. Uniłowski, Metaliteratura w pisarstwie Parnickiego..., s. 95.

35 Ibidem, s. 105.

${ }^{36}$ Inną gałęzią byłaby historia (historie) literatury, która może być zasadą porządkowania archiwum, jednak częściej bywa sugestywną narracją. 
poprawiaczem (ZK, s. 184) - czy jest Bogiem, czy złośliwym duchem? Autor zyskuje w oczach bohaterów cechy boskie, bowiem kreuje ich świat, wydaje im polecenia i zakazy, poza tym występuje tu teologiczna relacja twórca stworzenie. Jeszcze w „Epilogu” trwa dochodzenie: kim jest ON, kim jest autor? Skoro to nie Tarantula ani Diaz czy Boniecki, musi być nim P.

Krytykę literacką uprawia Jan XXII (zaczął robić to już w powieści Tylko Beatrycze), broni jej przydatności oraz nadaje jej status wzniosłej sztuki (ZK, s. 278). W jej kategoriach chciałby dowieść, że „od pierwszych dwu wierszy Iliady do ostatnich słów Komedii boskiej jest twórczość wszelka literacka dziełem Szatana..." (ZK, s. 279) - rozumie więc funkcję projektującą krytyki, jest też przygotowany na zastrzeżenia wobec siebie jako krytyka. Wyraża także sądy o autorze; w tym przypadku - Tarantuli. Możemy tu wskazać na dwa przykłady: „Ty wierzysz, że słowo jest po to, aby wyrażać myśl, nie po to, ażeby ukrywać, maskować, cieniować, przeinaczać. Powtórzę: biedny głupi Tarantula" (ZK, s. 281) - mówi Jan XXII, by za chwilę dodać: ,„[...] w postaci każdej przez ciebie stwarzanej »ja « twoje własne powtarza się wciąż w coraz to innym przebraniu lub poza coraz to inną maską" (ZK, s. 283) ${ }^{37}$. Poza tym zmiany w doktrynie teologicznej, które papież próbuje wprowadzić (a więc „zamknięcie" zaświatów), są przyczynkiem do stworzenia projektu teologii literatury według Parnickiego.

Przejście od krytyki do teorii dokonuje się w „Epilogu”. Jeszcze na początku jezuici mówią o tej pierwszej, aby na samym końcu (po rozważaniach nad tym, kto naprawdę jest autorem) przejść do tej drugiej. ,[...] Nie jest to koniec romansu dopuszczalny w kategoriach wymagań teorii literatury czy w ogóle estetyki romantycznej" (ZK, s. 446). Dzięki temu mamy do czynienia z klamrą. W pierwszym liście do Apolonii Hermanaryk uprawia chrystoznawstwo (bogoznawstwo) i zastanawia się nad tym, który Bóg (katolicki czy ariański) go uratował. Za to w ostatniej części powieści bohaterowie ustalają, kto może być autorem romansu „Zabij Kleopatrę”. Uprawiają tym samym teologię literatury.

\section{Odczytanie postsekularne? Parnicki a wyczerpanie nowoczesności}

Parnicki lubował się w metaforyzowaniu swojego procesu twórczego. Przypomnieć możemy porównanie warsztatu pisarza, który przekuwa historię w literaturę, do warsztatu płatnerza (rzemieślnika artystycznego) wytwarzające-

37 Cytaty te są jeszcze na dodatek ,wypowiedzią w dziele o dziele” (tak jak to rozumie Danuta Danek), a więc mają funkcję metaliteracką. 
go zbroje ${ }^{38}$. Mnie interesuje jednak związek literatury i teologii. Jak powiada Parnicki:

Teologia i kosmogonia platońska przedstawia Stworzyciela świata i wszechrzeczy jako kogoś, kto wprawdzie tworzy w sposób taki, jaki chce, ale ograniczony jest przez materiał, jaki ma do swej dyspozycji i jakiego sam sobie nie stworzył. Przeciwnie w teologii chrześcijańskiej: pierwsza osoba Trójcy, czyli Bóg Ojciec, tworzy z niczego. Podobnie mówić można o całym szeregu odmian literatury w ogóle, a powieściopisarstwa w szczególności, o wątkach, motywach, postaciach. Możemy więc powiedzieć, że - czy to Hamlet (jakkolwiek był kiedyś Hamlet historyczny), czy ksiądz Robak, czy Wokulski są dziełami pomysłu własnego swojego twórcy. Natomiast powieściopisarza historycznego porównywałbym w kategoriach analogii z teologią chrześcijańską - do drugiej osoby Trójcy - mianowicie do tego Chrystusa Zbawiciela, który nie tworzy, ale który wskrzesza tych, którzy umarli. I mnie się też zdawało, że ambicje powieściopisarza historycznego sprowadzają się właściwie do tego, żeby wskrzeszać to, co kiedyś naprawdę istniało, ale znowuż [...] chyba w żadnej powieści historycznej [...] nie jest i nie może być realnym odbicie sytuacji i postaci, jakie kiedyś były i - jeśli wolno użyć takiego wyrażenia - ,umarły”, bo czy to postać, czy sytuacja wskrzeszona przełamuje się zawsze poprzez osobowość twórcy: podobnie w pewnych apokryfach starochrześcijańskich Łazarz już nie był tym samym Łazarzem, jakim był przed swoją śmiercią, ale miał w sobie coś z osobowości tego, który go wskrzesi ${ }^{39}$.

Bohaterowie powieści odgadli więc intencje pisarza: jest przetwórcą-wskrzesicielem i wcale nie najwyższą instancją w hierarchii boskich bytów.

W drugiej fazie twórczości Parnickiego to wskrzeszanie polega po prostu na odtwarzaniu realiów i postaci historycznych, które stają się bohaterami powieściowymi. W późniejszym okresie ma ono już nieco inny charakter, bo sam autor prowadzi z postaciami znanymi z historii dialogi urojone. Jako pisarz coraz śmielej zmierza $\mathrm{w}$ stronę dyskursywnych konstrukcji, przypominających nekromancję i ,gadanie z duchami”. Taki gest ma oczywiście swoje historycznoliterackie źródła w tradycji antycznego dialogu (przede wszystkim Dialogów Lukiana z Samosat, który często wprowadzał do swoich utworów postaci historyczne, zmarłych, a nawet pojęcia abstrakcyjne) oraz - o czym pisarz sam wspomina - w Godzinie śródziemnomorskiej Jana Parandowskiego ${ }^{40}$.

38 T. Parnicki, Historia w literaturę przekuwana, Warszawa 1980, s. 33-39.

39 W. Jamroziak, Rozmowa z Teodorem Parnickim, „Nurt” 1971, nr 1, s. 5-6.

40 O wprowadzaniu dialogów urojonych do swojej twórczości mówi Parnicki tak: „Naprawdę dopiero śmiałości mi dodał Jan Parandowski i jestem mu za to ogromnie wdzięczny; przypłynął do mnie z Polski do Meksyku jego tom Godzina śródziemnomorska i tam znalazłem dialog między samym Parandowskim a Horacym. Uznałem dialog ten za pośrednie wprawdzie, ale bezsporne błogosławieństwo i dla mnie też, żebym już śmiało wystą- 
Jeśli jesteśmy w kręgu nawiązań biblijnych, to zwróćmy uwagę, że w Ewangeliach znajdziemy dwa opisy wskrzeszenia. Pierwszy z nich to wskrzeszenie Łazarza (J 11, 1-44), drugi - ciekawszy - to opis wskrzeszenia córki Jaira, który pojawia się w trzech Ewangeliach ${ }^{41}$. Jezus od początku wiedział, że dziewczynka nie żyje (mówi do Jaira: „Nie bój się, wierz tylko!” [Mk 5, 36]), następnie - jeszcze jej nie widząc! - oznajmia, że dziewczynka śpi, a dopiero później - w wąskim gronie (Piotr, Jakub, Jan oraz rodzice - to zaznaczono u Marka i Łukasza) dokonuje wskrzeszenia („Dziewczynko, wstań!” [Łk 8, 54]). Na samym końcu zakazuje rozpowiadania o tym wydarzeniu. Widzę tę scenę (nie jest to wszakże poparte studiami biblistycznymi ${ }^{42}$ ) jako opowieść o interpretacji. Wydarzenie nie jest dostępne, mamy tylko opowieść o wydarzeniu: spała czy zmarła? Zbudził czy wskrzesił? Jezus wiedział, że im gorliwej zakaże ludziom rozpowiadania, tym szybciej wieść się rozniesie. Co się stało w domu Jaira? To już kwestia interpretacji (bądź wiary) ${ }^{43}$.

Wróćmy jeszcze do Hermanaryka z „Zabij Kleopatrę”. Zastanawia się on nad tym, który Bóg go uratował: ariański czy katolicki. Apolonia jest za to najpewniej monofizytką, mamy więc do czynienia z trzema doktrynami chrystologicznymi, z których dwie zostały uznane za herezję. Arianizm, potępiony na soborze nicejskim (rok 325), uznawał Jezusa za pochodzącego od Ojca i stworzonego przez Niego, a na dodatek zakładał, że był czas, kiedy Jezusa nie było (miał więc być stworzony niejako „później”). Nauka Ariusza głosiła też, że Chrystus nie jest Bogiem, a tylko stworzeniem wyposażonym w moc Boga - innymi słowy, nie jest współistotny (humousios) Bogu. Monofizytyzm był doktryną uznającą w Chrystusie dwie natury, lecz natura boska miała wchłonąc naturę ludzką. Ruch ten potępiono w roku 451 na soborze chalcedońskim ${ }^{44}$. Diofizy tyzm jest więc w pewnym sensie „oficjalną”

pił z formą dialogu urojonego" (L. Budrecki, Między autobiografia a historia. (Rozmowa z Teodorem Parnickim), „Kultura” 1972, nr 30, s. 3). Chodzi o rozmowę Piotra z Horacym w tekście Rozmowa z cieniem. Zob. J. Parandowski, Godzina śródziemnomorska, wyd. III, Warszawa 1970, s. 153-195.

${ }^{41}$ Mt 8, 23-26; Mk 5, 35-43; Łk 8, 49-55. U Marka i Łukasza opisy tego wydarzenia są bardziej szczegółowe.

${ }^{42} \mathrm{Na}$ tę myśl naprowadził mnie fragment w powieści: J. Dukaj, Lód, Kraków 2007, s. 277. Pisałem o tym, choć w nieco innym kontekście, w: P. Gorliński-Kucik, TechGnoza, uchronia, science fiction. Proza Jacka Dukaja, Katowice 2017, s. 357-358.

${ }^{43}$ Tego rodzaju refleksje na temat interpretacji snuje Adam Regiewicz [w:] idem, Kerygmatyczne figury interpretacji, Kraków 2016.

44 Bóg czterech soborów (Nicea - 325, Konstantynopol I - 381, Efez I - 431 i Chalcedon - 451) jest Bogiem katolickim. Monofizytka Apolonia zamiast Chalcedonu wstawia Sobór Efeski II (449), który przyjął monofizytyzm. Następujący dwa lata później sobór w Chalcedonie uznał Sobór Efeski II za nieprawowierny i potępił monofizytyzm. Por. ZK, s. $8-24$. 
doktryną chrystologiczną (przyjętą w Chalcedonie w roku 451) - wedle niej Chrystus posiada naturę i ludzką, i boską, złączone w unii hipostatycznej (i co za tym idzie: dwie wole) ${ }^{45}$.

Wydaje się, że rozterki teologiczne bohaterów „Zabij Kleopatrę”, jakkolwiek istotne same w sobie, czyli w realiach powieści historycznej, odnoszą się także metaforycznie do postaci autora. Który Bóg uratował (uratuje) Hermanaryka, wydaje się w istocie znaczyć: który autor go uratuje? Dokładniej rzecz ujmując - w świetle słów samego Parnickiego z udzielonego Wojciechowi Jamroziakowi wywiadu - który Chrystus-wskrzesiciel to uczyni. Czy ten, który ma jedynie boską moc, ale sam Bogiem nie jest (ariański), ten o naturze boskiej, która wchłonęła ludzką (monofizycki), a może ten, który jest hipostatycznym połączeniem Boga i człowieka (diofizycki, katolicki, prawowierny)? W powieści Parnicki nie daje na to pytanie odpowiedzi ostatecznej i jednoznacznej, ale wydaje się, że kieruje się w stronę diofizytyzmu, a w każdym razie pozwala dojść do głosu ludzkiej naturze Chrystusa/autora. Sam Parnicki uznaje Jezusa za mieszańca ${ }^{46}$ : ścierają się w nim bowiem dwie natury, ludzka i boska. Stąd już tylko krok do dialogu urojonego, który jest właśnie ciągłą dyskusją (negocjacją) dwóch natur w każdym z mieszańców.

Jak metafora autora jako Chrystusa-wskrzesiciela i mieszańca przekłada się na konwencję powieści historycznej? Wydaje się, że z czasem we wskrzesicielu-autorze coraz głośniej przemawia natura ludzka. Parnicki polemizuje z wzorcem powieści dziewiętnastowiecznej, w której dominował wszechwiedzący, obiektywny narrator. Narrator Parnickiego jest coraz mniej transcendentny względem tekstu, immanentyzuje się, schodzi z piedestału, aż w końcu sam autor polemizuje ze swoimi bohaterami. W późniejszych powieściach będzie on - za sprawą dialogu urojonego - odbywał debaty ze swoimi postaciami.

Po raz pierwszy związki teorii literatury i teologii oraz konsekwencje z nich płynące zauważył Jacek Łukasiewicz: „Poniekąd teologia służy wyjaśnianiu tajemnic pisarstwa, dostarczając odpowiednich dystynkcji i analogii, ale także przeciwnie - to teoria literatury staje się służką teologii (ancilla

${ }^{45}$ Zob. B. Kumor, Historia Kościoła, t. I: Starożytność chrześcijańska, Lublin 2003; M. Banaszak, Historia Kościoła, t. I: Starożytność, wyd. II, Warszawa 2005; M. Simon, Cywilizacja wczesnego chrześcijaństwa I-IV wiek, wyd. III, przeł. E. Bąkowska, Warszawa 1992.

46 „Zresztą - o ile wolno mi pozwolić sobie na pewien paradoks - Chrystus w pełni Bóg i równocześnie w pełni - człowiek, według teologii soboru chalcedońskiego z roku 451 jest symbolem najwyższej formy mieszańca" (K. Nastulanka, Rozmowa z Teodorem Parnickim, „Polityka” 1968, nr 9, s. 7). 
teologiae) - problematów Stworzenia i Wcielenia" "47. Zauważa on, że Parnicki widział artystę-Boga jako twórcę nie ex nihilo czy z emanacji, ale jako tego, który tworzy z istniejącego (historycznego) materiału.

Postaci buntują się jednak - przede wszystkim - przeciw autorowi. Kalikrates mówi:

Mnie nie uciszysz łatwo. Spróbuj, jeżeli masz na to ochotę, właśnie teraz zawołać: postacie romansu milczą, gdy milczeć każe im autor! Rozchybotałeś swoją wyobraźnię autorską; masz nad nią dokładnie tyle władzy teraz, co dziecko nad huśtawką. Nie jest to zawód całkowicie bezkarny pisarstwo!

Odłożysz pióro? Będziesz także i dalej jeszcze słyszał mnie. Położysz się spać?

Będę ci się śnił (ZK, s. 311-312).

Bunt przeciw historii ma już zupełnie inny charakter. Hermanaryk i Apolonia chcą się pobrać, na co autor powieści historycznej wiernej źródłom nie może pozwolić. Są oni jednak skopiowani do pamięci operacyjnej, jaką jest ekskluzja/inkluzja, do ślubu więc ostatecznie dochodzi (ZK, s. 391-392). W rezultacie powstaje motyw historyczno-fantastyczny, który nie przeczy historii. Autor jest bogiem (tekstowego) świata i dlatego stwarza, a dokładniej rzecz ujmując: przetwarza bądź dotwarza z materiału historii. Pisanie/czytanie jest sposobem na życie. Świat podlega tu tym samym działaniom co tekst: można go nie tylko czytać, ale też pisać, można go także analizować, a skoro autor jest wpisany w swoje pisarstwo - może poddawać siebie nieustannej autoanalizie i zapisywać jej wyniki. Pisanie/czytanie świata/tekstu jest więc jednocześnie drogą do (auto)poznania.

Opieram się na kilku znakomitych tekstach ${ }^{48}$, które - chociaż wyraźnie podkreślają zróżnicowanie refleksji w obrębie tego nurtu - to jednak zgodnie zaznaczają, że zasadza się on na „dyskontynuacji czy dekonstrukcji stojącej

47 J. Łukasiewicz, „Pomnożyciel lat jego”..., s. 190. Autor szkicu także odwołuje się do doktryn chrystologicznych.

${ }^{48}$ Skromny przegląd otwierają trzy teksty znajdujące się w: Drzewo poznania. Postsekularyzm w przekładach i komentarzach, red. P. Bogalecki, A. Mitek-Dziemba, Katowice 2012, a są to: T. Sławek, Ratujace niebezpieczeństwo postsekularyzmu. Słowo wstępne (s. 9-24); P. Bogalecki, A. Mitek-Dziemba, Drzewo poznania. Wprowadzenie do myśli postsekularnej (s. 25-51); A. Bielik-Robson, Postowie (s. 346-364). Pozostałe to: K. Jarzyńska, Postsekularyzm - wyzwanie dla teorii i historii literatury (rozpoznania wstęne), „Teksty Drugie” 2012, nr 1-2; K. Jarzyńska, Powieść postsekularna po polsku (rekonesans) [w:] Metamorfozy religijności w literaturze nowoczesnej, red. A. Bielak, Lublin 2015, s. 171-189; K. Jarzyńska, Bywaliśmy świeccy. Postsekularne spojrzenie na polska formację modernistyczna [w:] Szkoda, że Cię tu nie ma. Filozofia religii a postsekularyzm jako wyzwanie nowych czasów, red. M. Ciesielski, K. Szewczyk-Haake, Kraków 2018, s. 115-130; A. Bielik-Robson, „Na pustyni”. Kryptoteologie późnej nowoczesności, Kraków 2008. 
za nim [...] wielkiej opowieści europejskiego sekularyzmu" "49 i że stanowi „wyrosłą na glebie późnej nowoczesności próbę reinterpretacji zagadnień teologicznych i religijnych, wiodących dziś żywoty świeckie, nieoczywiste i widmowe" ${ }^{50}$. Z „Zabij Kleopatrę” może być zatem nie lada problem. Nie trzeba tu bowiem wyczytywać ,ukrytej” duchowości (jak na przykład w Solaris Stanisława Lema ${ }^{51}$. Nie mamy do czynienia z kryptoteologią - przeciwnie: karzeł teologii nie siedzi ukryty w maszynie - siedzi (przynajmniej do pewnego czasu) przy szachownicy i ogląda zgrane, nieużywane już figury (monofizytyzm, diofizytyzm, arianizm), wspominając dawne, spektakularne bitwy przez nie toczone ${ }^{52}$ (ich przywołanie może być zresztą uznane za realizowanie wyznaczników gatunkowych powieści historycznej ,,pokrzepiającej mózgi").

Mamy tu zatem do czynienia z ruchem jak gdyby odwrotnym: jawne użycie teologicznych dyskursów starożytności chrześcijańskiej (wraz z rozpadem powieściowości) stanowi pewną metaforę - mówi o czymś innym, niż się na pierwszy rzut oka wydaje.

Pojawienie się ekstradiegetycznego opowiadacza (autora, narratora) w diegetycznym świecie to metaleptyczna transgresja, a zatem jedno z narzędzi postmodernistycznej poetyki. Metamorfozę metalepsy z retorycznego chwytu w kategorię narratologiczną opisał (a w zasadzie skonstruował) Gérard Genette w Figures III, co - wraz z szeroką egzemplifikacją - kapitalnie w swoim tekście (wobec którego zaciągam tu znaczny dług) pokazał Tomasz Swobo$\mathrm{da}^{53}$. Metalepsa polega na zetknięciu poziomu narracji i poziomu wydarzeń, co doprowadza do zmiany ich statusu ontologicznego. Tak powstaje heterometalepsa, jakieś somewhere, czyli inkluzja/ekskluzja, w której autor spotyka się ze swoimi postaciami ${ }^{54}$. Jakkolwiek granica pomiędzy intratekstualnym a ekstratekstualnym światem nie zostaje naruszona - to jednak czytelnik (na wzór

${ }^{49}$ P. Bogalecki, Kamień odrzucony. Postsekularyzm jako perspektywa interpretacyjna literatury i kultury polskiej, „Wielogłos” 2016, nr 3, s. 117.

${ }^{50}$ Ibidem, s. 115.

${ }^{51}$ Nie będą tu też pasować „wyznaczniki powieści postsekularnej” Johna McClure'a (zob. T. Umerle, Literacki postsekularyzm Johna McClure'a, „Wielogło”” 2015, nr 2) z racji innego charakteru materiału. „Odgórna sekularyzacja PRL-u” (zob. P. Bogalecki, op.cit., s. 117-118) też do Parnickiego pasować nie może, bo jego „prywatna sekularyzacja”, będąca pokłosiem biografii, przebiegała innymi torami.

${ }_{52}$ W. Benjamin, O pojęciu historii, przeł. K. Krzemieniowa [w:] idem, Anioł historii. Eseje, szkice, fragmenty, oprac. H. Orłowski, Poznań 1996, s. 413.

${ }_{53}$ T. Swoboda, Zakrzywienie przestrzeni reprezentacji. Parę stów o metalepsie, „Teksty Drugie" 2005, nr 5. Autor komentuje też rozprawy ze zbioru: Métalepses. Entorses au pacte de la représen tation, sous la dir. de J. Pier et J.-M. Schaeffer, Paris 2005.

${ }^{54}$ T. Swoboda, op.cit., s. 189-190. 
bohaterów „Epilogu” powieści „Zabij Kleopatrę” - pozostaje z niemiłym uczuciem, że w takim razie może i on, i jego pozatekstowy świat jest czyimś tekstem. W tym właśnie widzę postsekularną moc metalepsy.

Sądzę, że Parnicki użył dyskursów teologicznych z początków chrześcijaństwa oraz rozpadu powieściowości, aby opowiedzieć o czymś zgoła współczesnym. To metafora rozpadu struktur, dekonstrukcji transcendentnego autorytetu oraz konstrukcji pre-post-nowoczesnego podmiotu.

Skoro bowiem bohaterowie powieści są świadomi swojej tekstualności (tego, że są „zrobieni” przez rozmaite dyskursy ${ }^{55}$ ), chcą uzyskać wpływ na swój los, wyrywając się spod autorytarnej władzy opowiadacza, domagają się komunikacji z tymże zewnętrznym, naddanym z góry autorytetem (i komunikują się w tych kwestiach ze sobą nawzajem), to buntują się właśnie przeciw ustalonym arbitralnie zasadom/strukturom, żądają uznania swoich podmiotowych żądań. Buntują się, odmawiają współpracy na dotychczasowych warunkach i negocjują nowe - uwzględniające ich interesy. I odnoszą sukces - autor (Bóg o mieszanej, bosko-ludzkiej naturze, w którym ludzka natura przeważa coraz wyraźniej) ustępuje i rozpoczyna negocjacje, oddaje pole, ba - gdy weźmiemy pod uwagę kolejne powieści Parnickiego - wręcz oddaje się pod ich władzę. ,Zabij Kleopatrę" to (pojawiające się już w tytule) wezwanie do autorobójstwa, do buntu, zanegowania istniejących dotąd zasad komunikacji i władzy oraz do skonstruowania nowego typu podmiotowości partycypacyjnej.

Jeśli tak odczytać ten gest Parnickiego, skądinąd wiernego czytelnika Nietzschego (z którego pełnymi garściami czerpią poststrukturaliści i postmoderniści), to okazuje się, że wydana w 1968 roku - pozornie szalona - powieść staje się jednym z głosów przełomu, i to bardzo podówczas aktualnym. To prawda, że „struktury nie wychodzą na ulice" ${ }^{56}$ - wychodzą na nie domagające się przeformułowań podmioty. Pamiętajmy słowa Kalikratesa-buntownika: „Spróbuj, jeżeli masz na to ochotę, właśnie teraz zawołać: postacie romansu milczą, gdy milczeć każe im autor! [...] Odłożysz pióro? Będziesz także i dalej jeszcze słyszał mnie. Położysz się spać? Będę ci się śnił" (ZK, s. 311-312). Żeby powiedzieć już całkiem wprost: oto symptom przełomu poststrukturalnego. Tak jak po roku 1968 trzeba w inny sposób pojmować świat nowoczesny, tak po „Zabij Kleopatrę” należy w inny sposób pojmować wzorce dziewiętnastowiecznej czy nawet dwudziestowiecznej powieści histo-

55 Bardziej niż czytanie Parnickiego jako „ostatniego pisarza bytu” - zgodnie z interpretacją Stefana Szymutki - przekonuje mnie „herezja tekstualistyczna”. Taką lekturę powieści autora Stowa i ciała proponował Krzysztof Uniłowski, a przed nim - Tadeusz Komendant (zob. T. Komendant, Parnicki jak pismem sięgnać, „Polityka-Kultura” 1994, nr 5, s. VIII).

56 To jedno z haseł francuskiego maja 1968 roku. 
rycznej ${ }^{57}$. Dlatego właśnie użyłem do opisu rozpadu kategorii powieściowych języka strukturalnego i tabel - chciałem jak najwyraźniej uwidocznić rozpad kolejnych pięter tej struktury i zasad komunikacji nią rządzących.

Może zatem postsekularyzm Parnickiego to ten postsekularyzm, który reprezentowali Rosenzweig, Benjamin, Bloch, Adorno czy Horkheimer, czyli ,[...] ruch powstały w Europie Środkowej w reakcji na dwudziestowieczne totalitaryzmy, wykorzystujący elementy dyskursu teologicznego do wewnętrznej krytyki nowoczesności” 58 ? Wtedy „Zabij Kleopatrę” byłaby nie tylko opowieścią o tym, jak brzydki karzeł teologii chowa się pod stół, czy o tym, jak coraz bardziej ludzki Chrystus-wskrzesiciel „zstępuje do świata”. Mówiłaby nam przede wszystkim o tym, jak za każdym razem odzyskiwany zostaje świat (w trakcie kształtowania się doktryny chrześcijańskiej, procesów sekularyzacji, wykuwania się podmiotów nowoczesnych, w momencie zwrotu poststrukturalnego), gdy Bóg/transcendentny autorytet/autor stopniowo chowa słońce swojej władzy, aby delikatnie go oświetlać5 ${ }^{59}$, i o tym, że partycypacyjne podmioty wychodzą wtedy na „pustynię samostanowienia”. Za każdym razem - kawałek dalej.

\section{Bibliografia}

Alighieri D., Boska komedia, przeł. E. Porębowicz, Kraków 2003.

Banaszak M., Historia Kościoła, t. I: Starożytność, wyd. II, Warszawa 2005.

${ }^{57}$ Por. „Metaprozę Parnickiego wypadałoby zatem traktować jako swoistą transgresję, przedłużenie, przekroczenie, a zarazem dialektyczne zniesienie gatunkowej formuły prozy historycznej [...]" (K. Uniłowski, Historia, dekonstrukcja, metaproza..., s. 147), także: „[...] [Powieści Parnickiego - przyp. P.G.K.] wyprowadzają nas z potrójnej niewoli: po pierwsze - prawa metafizyki, po drugie - metafizycznie pojętego prawa, po trzecie - niewoli historyczności pojmowanej bądź to jako historyczny determinizm, bądź jako przeznaczenie, jako scena, na której musi się rozegrać dramat egzystencjalnej skończoności. Tej potrójnej opresji Parnicki przeciwstawia rozważanie, dociekanie, krytykę, krótko mówiąc pisanie pojmowane jako przekraczanie granic gatunkowych, rodzajowych, historycznych i egzystencjalnych". Ibidem, s. 148.

${ }^{58}$ K. Jarzyńska, Bywaliśmy świeccy..., s. 125.

59 Odwołuję się do inspirującego eseju Agaty Bielik-Robson, która pisze wprawdzie o powstawaniu literatury nowoczesnej (a nie jej wyczerpaniu). Zob. A. Bielik-Robson, $L i$ terackie kryptoteologie nowoczesności, czyli o pierwszeństwie świata, „Wielogłos” 2015, nr 2, s. 13-28. „Żeby świeckość mogła się stać domeną nowej formy pasji, która zrodziła nowożytną literaturę, musiała najpierw zaistnieć pobożność, kierująca całą swą namiętność na Deus solus. I żeby świat mógł wyjść na jaw jako wielki temat literacki, Bóg musiał dyskretnie schować się w zaświaty, niczym Heglowskie słońce za horyzont, albo, wzorem Benjaminowskiego karła - pod stół". Ibidem, s. 18. 
Benjamin W., O pojęciu historii, przeł. K. Krzemieniowa [w:] idem, Anioł historii. Eseje, szkice, fragmenty, oprac. H. Orłowski, Poznań 1996, s. 413-425.

Bielik-Robson A., Literackie kryptoteologie nowoczesności, czyli o pierwszeństwie świata, ,Wielogłos” 2015, nr 2, s. 13-28.

Bielik-Robson A., ,, Na pustyni”. Kryptoteologie późnej nowoczesności, Kraków 2008.

Bogalecki P., Kamień odrzucony. Postsekularyzm jako perspektywa interpretacyjna literatury i kultury polskiej, „Wielogłos” 2016, nr 3, s. 113-130.

Budrecki L., Między autobiografia a historia. (Rozmowa z Teodorem Parnickim), „Kultura” 1972, nr 30, s. 1, 3.

Czermińska M., Autotematyczność $i$ dystans czasowy w powieściach Parnickiego [w:] O prozie polskiej XX wieku, red. A. Hutnikiewicz, H. Zaworska, Wrocław 1971, s. 311-331.

Czermińska M., Czas w powieściach Parnickiego, Warszawa 1972.

Czermińska M., Teodor Parnicki, Warszawa 1974.

Danek D., O polemice literackiej w powieści, Warszawa 1972.

Drzewo poznania. Postsekularyzm w przektadach $i$ komentarzach, red. P. Bogalecki, A. Mitek-Dziemba, Katowice 2012.

Dukaj J., Lód, Kraków 2007.

Głowiński M., Narracja jako monolog wypowiedziany [w:] idem, Gry powieściowe. Szkice z teorii i historii form narracyjnych, Warszawa 1973, s. 106-148.

Głowiński M., ,, Nouveau roman” - problemy teoretyczne [w:] idem, Porzadek, chaos, znaczenie. Szkice o powieści współczesnej, Warszawa 1968, s. 35-89.

Głowiński M., Powieść jako metodologia powieści [w:] idem, Porzadek, chaos, znaczenie. Szkice o powieści współczesnej, Warszawa 1968, s. 90-136.

Gombrowicz W., Dziennik 1961-1966, wyd. II, Kraków 1989.

Gorliński-Kucik P., Meksykańskie lata Teodora Parnickiego [w:] Literatura polska obu Ameryk. Studia i szkice. Seria pierwsza, red. B. Nowacka, B. Szałasta-Rogowska, Katowice-Toronto 2014, s. 589-605.

Gorliński-Kucik P., TechGnoza, uchronia, science fiction. Proza Jacka Dukaja, Katowice 2017.

Hutcheon L., Teoria parodii. Lekcja sztuki XX wieku, przeł. A. Wojtanowska, W. Wojtowicz, Wrocław 2007.

Jamroziak W., Rozmowa z Teodorem Parnickim, „Nurt” 1971, nr 1, s. 5-8.

Jarzyńska K., Bywaliśmy świeccy. Postsekularne spojrzenie na polska formację modernistyczna [w:] Szkoda, że Cię tu nie ma. Filozofia religii a postsekularyzm jako wyzwanie nowych czasów, red. M. Ciesielski, K. Szewczyk-Haake, Kraków 2018, s. $115-130$.

Jarzyńska K., Postsekularyzm - wyzwanie dla teorii i historii literatury (rozpoznania wstęne), „Teksty Drugie” 2012, nr 1-2, s. 294-307.

Jarzyńska K., Powieść postsekularna po polsku (rekonesans) [w:] Metamorfozy religijności w literaturze nowoczesnej, red. A. Bielak, Lublin 2015, s. 171-189.

Juszczyk A., Retoryka a poznanie. Powieściopisarstwo Teodora Parnickiego, Kraków 2004. 
Komendant T., Parnicki jak pismem sięgnąć, „Polityka-Kultura” 1994, nr 5, s. VIII.

Koziołek R., Co to jest Z.? Postać literacka w przestrzeni intertekstualnej: Parnickiego „I u możnych dziwny”, „Pamiętnik Literacki” 1994, z. 1, s. 102-122.

Kumor Z., Historia Kościoła, t. I: Starożytność chrześcijańska, Lublin 2003.

Łamigłówki historii. Z Teodorem Parnickim rozmawia Krystyna Nastulanka, „Polityka" 1968, nr 9, s. 1, 7.

Łebkowska A., Fikcja jako możliwość. Z przemian prozy XX wieku, wyd. II uzup., Kraków 1998.

Łukasiewicz J., ,, Gliniane dzbany” [w:] idem, Republika mieszańców, Wrocław 1974, s. $235-250$.

Łukasiewicz J., „Pomnożyciel lat jego”... Teoria literatury, czyli teologia [w:] Świat Parnickiego. Materiały z konferencji, red. J. Łukasiewicz, Wrocław 1999, s. 187194.

Mętrak K., „Powieść to jakby rozwiazywanie łamigłówki...”. Rozmowa z Teodorem Parnickim, „Kultura” 1968, nr 32, s. 1, 3.

Okopień-Sławińska A., Relacje osobowe w literackiej komunikacji [w:] Problemy teorii literatury, S. 2: Prace z lat 1965-1974, red. H. Markiewicz, Wrocław 1987, s. $27-41$.

Parandowski T., Godzina śródziemnomorska, wyd. III, Warszawa 1970.

Parnicki T., Historia w literaturę przekuwana, Warszawa 1980.

Parnicki T., I u możnych dziwny. Powieść z wieku XVII, Warszawa 1979.

Parnicki T., Tylko Beatrycze. Powieść historyczna, Wrocław 2001.

Parnicki T., ,Zabij Kleopatre”, Warszawa 1968.

Pismo Święte Starego i Nowego Testamentu, oprac. zespół biblistów polskich, wyd. III popr., Poznań-Warszawa 1980.

Regiewicz A., Kerygmatyczne figury interpretacji, Kraków 2016.

Simon M., Cywilizacja wczesnego chrześcijaństwa I-IV wiek, wyd. III, przeł. E. Bąkowska, Warszawa 1992.

Swoboda T., Zakrzywienie przestrzeni reprezentacji. Parę słów o metalepsie, „Teksty Drugie" 2005, nr 5, s. 183-194.

Szybist M., Doktryna twórcza i sztuka T. Parnickiego, „Życie Literackie” 1971, nr 21, s. 3, 14 .

Szymutko S., Koniec porozumienia z odbiorca (O odmianie powieści historycznej, stworzonej przez T. Parnickiego) [w:] Studia o przemianach gatunkowych w powieści polskiej XX wieku, red. T. Bujnicki, Katowice 1987, s. 116-138.

Umerle T., Literacki postsekularyzm Johna McClure'a, „Wielogłos” 2015, nr 2, s. $1-12$.

Uniłowski K., Historia, dekonstrukcja, metaproza. O dwóch powieściach Teodora Parnickiego [w:] idem, Prawo krytyki. O nowoczesnym i ponowoczesnym pojmowaniu literatury, Katowice 2013.

Uniłowski K., Metaliteratura w pisarstwie Parnickiego, „Pamiętnik Literacki” 1991, z. 2, s. 90-122. 